\title{
PERSEPSI LABEL HALAL TERHADAP KEPUTUSAN PEMBELIAN KONSUMEN PADA PRODUK MINUMAN BERENERGI
}

\author{
Aris Setyawan Prima Sandi ${ }^{1}$, Marsudi², Dedy Rahmawanto ${ }^{3}$ \\ Universitas Muhammadiyah Malang \\ E-mail: aris.estyawan99@gmail.com, marsudi@umm.ac.id, dedi@umm.ac.id
}

\begin{abstract}
The aim of this research is to know the influence of consumer's perception of Halal label at energy beverage product on purchasing decision. Then it is also to know the correlation of consumer's perception of Halal label. Analyses method used multiple linier regression. Consumer's perception variables include attention, understanding and memory. The result of analysis show that consumer's perception (attention, understanding and memory) of Halal label simultaneously influence to decision of purchasing on energy beverage product. There are two independent variables partially significant influence to decision of purchasing. Two variables are attention and memory. The correlation coefficient for attention, understanding and memory variables with decision of purchasing variable is in strong level. It exemplified those attention, understanding and memory variables are very strong correlation to decision of purchasing.
\end{abstract}

Keywords: perception, halal label, decision of purchasing

\section{PENDAHULUAN}

Fenomena dalam kompetisi global dewasa ini, industri barang jadi produksi pabrik maupun maupun rumahan bersaing semakin ketat. Pasar semakin ramai dengan barang-barang hasil produksi tersebut.Konsumen memberikan persepsi terhadap suatu obyek atau barangakan berbedabeda, sebagian konsumen memberikan persepsi positif, dan sebagian lagi meberikan persepsi negatif, oleh karena itu persepsi mempunyai sifat subyektif.Pada pasar industri makanan dan minuman sekarang ini, telah banyak beredar minuman dalam botol yang tidak berlabel halalbaik secara legal maupun ilegal. Peredaran minuman dalam botol yang tidak berlabel halal tersebut dipasaran, memungkinkan persepsi konsumen tentang minuman dalam botol secara keseluruhan mejadi beragam ataupun menjadi negatif. Tidak terkecuali persepsi konsumen terhadap minuman berenergi dalam botol, karenafenomena yang menarik terjadi disebagian besarmasyarakatmodern yang umumnya tinggal diperkotaan, dalam hal mengatasi kelelahan dan mengatasi tambahan atas jumlah asupan energinya cenderung untuk memilih cara yang mudah, murah dan instan, yakni mengkonsumsi minuman berenergi cair dalam botol.

Bangsa Indonesia dengan masyarakatnya yang mayoritas memeluk agama Islam, sehingga pola konsumsinya juga secara mutlak tidak boleh terlepas dari aturan-Islam.Hukum Islam sangat jelas dalam hal konsumsi, yakni barang yang dikonsumsi harus bebas dari hal-hal yang tergolong haram atau tidak halal. Label halal yang tertera dalam suatu produk, menandakan kehalalan produk konsumsi tersebut. Keberadaan label halal pada minuman, khususnya minuman energi tentunya akan berpengaruh pada persepsi konsumen kepada produk minuman energi tersebut.

Majalah SWA online memberitakan bahwasanya penjualan dari salah satu merek minuman berenergi pada tahun 2009 mencapai Rp268 mili$\operatorname{ar}($ http://swa.co.id/ minuman berenergi).Angka penjualan yang tinggi untuk kelas produk makanan dan minuman. Majalah tersebut juga memprediksi 
penjualan minuman berenergi tersebut akan mengalami peningkatan terus menerus. Minuman berenergi tersebut juga meraih Indonesian Customer Satisfaction Award (ICSA) yang kesembilan kalinya pada 2010 sebagai merek terbaik untuk kategori minuman penambah tenanga dn juga meraih penghargaan platinum dari Indonesia Best Brand Award (IBBA) pada tahun 2010 sebagai produk terbaik dalam kategori minuman energi non-liquid (http://okezone. com).

Sejumlah penghargaan atas pencapaian-pencapaian penjualan pada level jumlah produk minuman berenergi diatas, membuktikan bahwasanya minuman berenergi disini telah cukup diminati masyarakat Indonesia yang mayoritas beragama Islam atau Muslim. Penghargaan atas pencapaianpencapaian penjualan tersebut memberi sedikit gambaran dini bahwasanya masyarakat Indonesia yang mayoritas adalah Muslim, memberikan persepsi yang positif kepada produk minuman berenergi yang berbentuk cair dalam botol.Hal yang menarik jika dikaitkan dengan fenomena peredaran minuman yang tidak berlabel halal.

Kemudian berdasarkan uraian diatas, maka dapat dirumuskan permasalahan sebagaiberikut: Bagaimana pengaruh persepsi konsumen atas label halal pada produk minuman berenergi terhadap keputusan pembelian konsumen, dan bagaimana korelasi antara persepsi konsumen atas pencantuman label halal pada produk minuman berenergi dengan keputusan pembelian.Agar permasalah tidak meluas dan tetap terarah, penulis menetapkan batasan masalah yang diteliti pada beberapa hal diantaranya adalah fokus penelitian hanya pada persepsi konsumen atas pencantuman label halal yang tertera pada kemasan minuman berenergi, penelitian ini terlepas dari berbagai masalah lain diluar minuman berenergi yang merupakan minuman yang bersifat instan (cair dalam botol), 1 . Mengetahui bagaimana pengaruh persepsi konsumen atas label halal pada produk minuman berenergi terhadap keputusan pembelian konsumen, 2. Mengetahui bagaimana korelasi antara persepsi konsumen atas pencantuman label halal pada produk minuman berenergi dengan keputusan pembelian. Penelitian ini diharapkan dapat membantu produsen dan manajer pemasaran dalam menentukan rencana dan strategi pemasaran produk, ser- ta memberikan pengetauan dasar untuk peneliti pemasaran ketika menganalisis perilaku konsumen khususnya persepsi konsumen.

\section{TINJAUAN PUSTAKA}

Beberapa kajian teoritis yang berhubungan dengan persepsi konsumen terhadap keputusan pembelian telah dilakukan sebelumnya. Dijelaskan oleh Laila Maya (2009) dengan judul "pengaruh persepsi terhadap resiko pembelian personal computer pada proses pengambilan keputusan membeli konsumen", diketahui bahwa Tidak terdapat pengaruh persepsi terhadap pembelian PC pada proses pengambilan keputusan membeli konsumen.

Ditambahkan pula oleh Mashadi (2008) dengan Judul "Pengaruh Motivasi, Persepsi, Sikap dan Pembelajaran konsumen terhadap keputusan pembelian Minuman Kemasan Merek Teh Botol Sosro di Kawasan Depok" menyebutkan bahwa ada pengaruh signifikan dari motivasi, persepsi, sikap dan pembelajaran konsumen terhadap keputusan pembelian minuman kemasan teh botol sosro di kawasan Depok.

Perilaku konsumen menggambarkan bagaimana tindakan manusia dalam memenuhi barang konsumsinya. Mowen dan Minor dalam Umar (2003:11) menyebutkan perilaku konsumen sebagai studi tentang unit pembelian (buying units) dan proses pertukaran yang melibatkan perolehan, konsumsi, dan pembuangan barang, jasa, pengalaman serta ide-ide. Dalam perkembangan konsep pemasaran modern, konsumen ditempatkan sebagai sentral perhatian. Konsumen menjadi titik ataupun pihak yang menjadi obyek dari pemasaran.

Konsep perilaku konsumen sangat terkait dengan pemasaran, dalam arti mengidentifikasikan dan memenuhi kebutuhan manusia dan kebutuhan sosial. Karena dalam menyusun konsep pemasaran, perilaku konsumen menjadi acuan studi untuk menetapkan strategi pemasaran yang akan diterapkan agar tepat serta sesuai sasaran. Loyalitas konsumen terhadap produk yang ditawarkan menjadi tolok ukur keberhasilan konsep pemasaran dan strategi pemasaran yang ditetapkan.

Perilaku konsumen mengacu pada bagaimana implikasi terhadap langkah-langkah strategi pemasaran. Mendalami tentang bagaimana perilaku kon- 
sumen, bertujuan untuk mengetahui dan memahami bagaimana aspek yang ada pada konsumen, yang akan digunakan dalam menyusun strategi pemasaran yang berhasil (Sutisna, 2002:5). Model perilaku konsumen menghubungkan pembeli baik dengan pengaruh individu maupun lingkungan.

Komponen pusat dari model ini adalah pembuatan keputusan konsumen yang terdiri atas proses merasakan dan mengevaluasi informasi terhadap merek produk, mempertimbangkan bagaimana alternatif merek dapat memenuhi kebutuhan konsumen, dan pada akhirnya memutuskan merek apa yang akan dibeli. Terdapat tiga faktor utama yang mempengaruhi keputusan konsumen. Faktor pertamakonsumen individual, yakni pilihan untuk membeli dipengaruhi oleh hal-hal yang ada pada diri konsumen. kedua yaitu pengaruh dari lingkungan yang ada di sekelilingnya. Ketiga yaitu stimuli pemasaran atau strategi pemasaran yang diterapkan perusahaan dalam menarik minat konsumen atas barang yang ditawarkan.

Pengambilan keputusan pembelian merupakan suatu kegiatan inividu yang secara langsung terlibat dalam mendapatkan dan menggunakan barang yang ditawarkan. Suatu proses keputusan membeli bukan sekedar mengetahui berbagai faktor yang akan mempengaruhi pembeli, tetapi berdasarkan peranan dalam pembelian dan keputusan untuk membeli. Proses ini merupakan penyeleseian masalah dalam membeli barang dan jasa untuk memenuhi kebutuhan konsumen.

Keputusan pembelian suatu produk oleh konsumen merupakan hasil dari proses yang panjang. Untuk sampai pada keputusan pembelian, konsumen melewati beberapa tahap pembelian seperti yang dikemukakan oleh Peter dan Olson (1999:164). Terdapat lima tahap yang harus dilalui dalam melakukan pembelian suatu produk, yaitu: 1) Proses dimulai pada saat konsumen menyadari adanya masalah atau kebutuhan. 2) Pencarian Informasi. 3) Evaluasi Alternatif. 4) Keputusan Pembelian. 5) Perilaku Purna Pembelian.

Minuman energi adalah jenis minuman yang ditujukan untuk menambah energiseseorang yang meminumnya. Bagi beberapa kalangan, minuman energi diminum dengan tujuan untuk mencegah kantuk (Anonymous, 2010). Suplemen penambah energi merupakan produk yang dapat melengkapi kebutuhan zat gizi makanan, mengandung be- berapa bahan berupa vitamin, mineral, efedrin, taurin, kafein, dan bahan lain yang mempunyai nilai gizi dan atau efek fisiologis dalam jumlah terkonsentrasi (Enny Sophia, 2009).

Suplemen berenergi termasuk salah satu suplemen makanan atau minuman yang terdiri dari komponen multivitamin, makronutrien (karbohidrat, protein), efedrin, taurin, kafein, dan biasanya ditambahkan herbal seperti ginseng, jahe, dengan bentuk cair, serbuk dan tablet yang dilarutkan menjadi minuman, dalam setiap kemasannya mengandung energi minimal $100 \mathrm{kkal}$, serta indikasinya adalah untuk menambah tenaga, kesegaran, stimulasi metabolisme, memelihara kesehatan dan stamina tubuh, yang diminum pada saat bekerja keras, olah raga atau setelah beraktivitas yang melelahkan (www.pom.go.id).

Label halal pada produk, dimaksudkan untuk memberikan informasi atau keterangan bahwa produk tersebut telah lulus uji kehalalan oleh lembaga yang berwenang melakukan pengujian kehalalan tersebut. lembaga yang berwenang melakukan uji kehalalan produk makanan dan minuman disini adalah LPPOM MUI yakni Lembaga Pengkajian dan Pengawasan Obat dan Makanan Majelis Ulama Indonesia. selanjutnya LPPOM MUI ini mengesahakan suatu produk yang telah lulus uji kehalalan menjadi produk konsumsi yang aman dan halal untuk dikonsumsi oleh umat Islam khususnya dan masyarakat keseluruhan pada umumnya.

Berdasarkan peraturan pemerintah Republik Indonesia nomor 69 tahun 1999 tentang label dan iklan pangan pada Bab I pasal 1, disebutkan bahwa label pangan adalah setiap keterangan mengenai pangan yang berbentuk gambar, tulisan, kombinasi keduanya, atau bentuk lain yang disertakan pada pangan, dimasukkan ke dalam, ditempelkan pada, atau merupakan bagian kemasan pangan, yang selanjutnya dalam Peraturan Pemerintah ini disebut Label. Pangan halal adalah pangan yang tidak mengandung unsur atau bahan yang haram atau dilarang untuk dikonsumsi umat Islam, baik yang menyangkut bahan baku pangan, bahan tambahan pangan, bahan bantu dan bahan penolong lainnya termasuk bahan pangan yang diolah melalui proses rekayasa genetika dan iradiasi pangan, dan yang pengelolaannya dilakukan sesuai dengan ketentuan hukum agama Islam. (Peraturan Pemerintah Republik Indonesia, 1999). 
Penjelasan tentang peraturan pemerintah diatas tentang label halal dan iklan pangan menerangkan bahwa pencantuman keterangan halal atau tulisan "halal" pada kemasan produk adalah merupakan kewajiban, apabila pihak yang memproduksi dan tau memasukan pangan kedalam wilayah Indonesia menyatakan bahwa produknya halal bagi umat islam. Keterangan tentang halal tersebut mempunyai arti yang sangat penting dan dimaksudkan untuk melindungi masyarakat yang beragama Islam agar terhindar dari melakukan pengkonsumsian pangan yang tidak halal (haram). Kebenaran suatu pernyataan halal pada label pangan tidak hanya dibuktikan dari segi bahan baku, bahan tambahan pangan, atau bahan bantu yang digunakan dalam memroduksi pangan, tetapi harus pula dibuktikan dalam proses produksinya.

Stanton dalam Setiadi (2010:88) menyebutkan persepsi dapat didefinisikan sebagai makna yang dipertalikan berdasarkan pengalaman masa lalu, stimuli (rangsangan) yang diterima melalui lima indra. Stimuli merupakan setiap bentuk fisik, visual atau komunikasi verbal yang dapat mempengaruhi tanggapan individu. Sedangkan menurut Sunarto (2003:50), persepsi adalah proses dimana individu diekspose untuk menerima informasi, memperhatikan, dan memahaminya. Persepsi konsumen terhadap suatu produk sangat dipengaruhi oleh proses penerimaan citra (image) dari produk tersebut pada waktu konsumen pertama kali melihat ataupun pertama kali mengetahui produk tersebut.

Persepsi tidak timbul begitu saja, sebelum menjadi persepsi yang dapat mempengaruhi psikologis konsumen, informasi yang diterima konsumen harus mendapatkan perhatian, pemahaman, dan ingatan dari konsumen (Sunarto, 2003:51). Model pengambilan keputusan kompleks mengidentifikasi empat langkah dalam pengolahan informasi, yakni 1).Penela'ahan informasi, 2).perhatian, 3). Pemahaman, 4).ingatan (Assael, 1992:112).

Agar konsumen dapat memahami informasi dan menempatkannya dalam memori untuk jangka panjang, maka konsumen harus memperhatikannya. Sekali konsumen terekspos pada informasi pemasaran, baik sengaja atau tidak sengaja maka proses interpretasi perhatian dan pemahaman dimulai (Peter dan Olson, 1999:106). Perhatian merupakan alokasi kapasitas kognitif ke sebuah obyek atau tugas, sehingga informasi secara sadar dapat diproses (Mowen dan minor, 2003:97). Perhatian konsumen dapat diaktivasi baik secara sengaja (voluntary attention) ataupun tidak disengaja (involuntary attention).

Apabila konsumen secara aktifmencari informasi yang relevan dengan pribadi mereka, maka perhatian tersebut dikatakan sukarela. Perhatian secara sukarela ini menandakan bahwasanya konsumen juga mempunyai keingintahuan akan barang yang akan dibeli tersebut.Perhatian tidak disengaja terjadi kepada konsumen ketika dipaparkan tentang sesuatu yang menarik, mengejutkan, atau sesuatu yang tidak diperkirakan, yang tidak ada relevansinya dengan tujuan atau kepentingan konsumen. Baik voluntary attention atau involuntary attention kedua-duanya memerlukan alokasi kapasitas kognitif dari konsumen terhadap stimulus tertentu (Setiadi, 2010:99).

Sunarto (2003:63) menyebutkan, para pemasar berusaha untuk merebut perhatian konsumen dengan memperbanyak variasi sifat dasar rangsangan yang mereka terima. Tujuannya adalah untuk mengaktivasi refleks orientasi dengan menciptakan efek rangsangan yang mengejutkan, mengancam, atau mengganggu harapan. Konsumen akan mencermati rangsangan (stimulus) yang diterima kemudian mengevaluasi apakah rangsangan yang berupa informasi yang diperolehnya untuk menentukan apakah hal ini cukup penting untuk diproses lebih jauh lagi atau tidak.

Pemahaman mengacu pada proses interpretasi yang melaluinya, konsumen memahami atau merasakan perilaku mereka dan aspek relevan lingkungan mereka. Pada tahap pemahaman dari pemrosesan informasi, konsumen secara perseptual mengorganisasikan dan menginterpretasikan informasi dalam rangka mendapatkan arti dari informasi itu. Pada proses interpretasi, konsumen mempergunakan pengalaman, memori, dan harapan untuk mengikatkan arti dengan rangsangan (Mowen dan minor, 2003: 102).

Sunarto (2003:65) menyebutkan bahwa, melalui proses interpretasi, konsumen akan sampai pada tahap pemahaman tentang apaitu rangsangan. Proses ini dimulai selama tahap perhatian dan berlanjut setelahnya, dimana konsumen berusaha untuk memperoleh pemahaman tentang apa rangsangan itu dan bagaimana mereka harus menanggapinya. Pada tahap interpretasi dari pemrosesan informasi ini, or- 
ang mencari kembali informasi jangka panjang dari memorinya yang tepat untuk informasi tersebut, serta harapan untuk rangsangan tersebut. Sehingga orang akan dengan mudah mencerna informasi tersebut.

Pengetahuan konsumen didefinisikan sebagai sejumlah pengalaman dengan informasi tentang produk atau jasa tertentu yang dimiliki seseorang. Dengan meningkatkan pengetahuan individu konsumen, memungkinkan bagi konsumen tersebut berpikir kembali tentang produk - produk yang sama yang beredar dipasaran. Konsumen akan lebih selektif untuk memilih produk yang dianggap paling sesuai dengan pengetahuannya dan apa yang telah dialami sebelumnya.

Proses pemahaman yang lebih dalam menciptakan lebih banyak abstraksi, lebih banyak arti berelevansi pribadi yang lebih cenderung diingat dengan lebih baik (tingkat ingatan dan pengenalan yang lebih tinggi) ketimbang arti lebih nyata yang dihasilkan oleh proses pemahaman yang dangkal (Peter dan Olson, 1999:116). Ingatan merupakan kemampuan yang memunginkan para konsumen untuk mengantisipasi rangsangan yang mereka hadapi, dan oleh karenanya mengekspose diri mereka secara selektifterhadap rangsangan yang diinginkan (Mowen dan minor, 2003:125). Memori mempengaruhi proses perhatian dengan mengarahkan sistem sensor konsumen, sehingga mereka dapat memfokuskan secara selektif pada informasi tertentu.

Sunarto (2003:75) menyebutkan, memori atau ingatan jangka panjang memiliki kapasitas tidak terbatas untuk menyimpan informasi secara permanen. Informasi yang disimpan dalam memori jangka panjang cenderung dilakukan secara visual ataupun sematik. Sematik merupakan arti verbal yang dikaitkan dengan kata - kata, kejadian, obyek dan symbol. Jadi, memori jangka panjang menyimpan arti kata - kata, symbol dan sebagainya bersama - sama dengan asosiasi diantara berbagai konsep sematik yang diperoleh. meori jangka panjang juga dapat menyimpan informasi dalam bentuk urutan kejadian (memori episode), modalitas (pandangan, penciuman, sentuhan), dan perasaan atau emosional serta rasa puas. Sifat permanen memori jangka panjang di ilustrasikan dengan keabadian nama merek yang terus diingat.

Persepsi setiap orang terhadap suatu obyek akan berbeda-beda, oleh karena itu persepsi mempunyai sifat subyektif. Persepsi yang di bentuk oleh seseorang akan dipengaruhi oleh isi memorinya. Semua yang pernah memasuki wilayah sensory dan mendapat perhatian yang selanjutnya diproses lebih jauh lagi kemudian akan disimpan dalam memori. Sehingga ketikamanusiamendapat stimulus, memori itu akan dibuka kembali dan menjadi referensi untuk menanggapinya (Sutisna, 2002:62).Stimulus adalah setiap bentuk fisik, visual atau komunikasi verbal yang dapat mempengaruhi tanggapan individu.

Dalam proses terciptanya keputusan pembelian, persepsi konsumen atas produk merupakan bagian yang tidak akan terpisahkan. Persepsi merupakan tahap dimana informasi yang diterima oleh konsumen diolah sedemikian rupa selanjutnya informasi tersebut disimpan didalam memori dan akhirnya tercipta sebuah interpretasi tentang sebuah produk. Persepsi dari hasil olahan informasi tersebut akan mempengaruhi perubahan tatanan psikologi konsumen akan sebuah produk.

Kajian teoritis yang berhubungan dengan persepsi konsumen terhadap keputusan pembelian telah dilakukan sebelumnya. Dijelaskan oleh Mashadi (2008) dengan Judul "Pengaruh Motivasi, Persepsi, Sikap dan Pembelajaran konsumen terhadap keputusan pembelian Minuman Kemasan Merek Teh Botol Sosro di Kawasan Depok" menyebutkan bahwa ada pengaruh signifikan dari motivasi, persepsi, sikap dan pembelajaran konsumen terhadap keputusan pembelian minuman kemasan teh botol sosro di kawasan Depok, terlihat dari hasil Uji-F dalam penelitian tersebut, dengan menggunakan signifikansi $(\alpha)=5 \%$ diperoleh nilai F-hitung 38,231 lebih besar dari nilai $F$ tabel 2,650. Begitu juga dengan Uji-t yang telah dilakukan, dari semua variabel tidak satupun yang mempunyai nilai thitung lebih kecil dari nilai t-tabel.

Persamaan penelitian ini dengan penelitian sebelumnya adalah sama-sama merupakan penelitian deskriptif, alat analisis yang dipakai yakni regresi linier berganda. Adapun perbedaan antara penelitian terdahulu dengan penelitian yang dilakukan adalah pada penelitian terdahulu penarikan sampel menggunakan teknik accidental sampling atau berdasarkan kebetulan, sedangkan penelitian ini menggunakan teknik convenience sampling atau berdasarkan kemudahan, dan juga peneliti terdahulu menggunakan Uji t-paired untuk menentukan ada tidaknya perbedaan rata-rata dua sampel bebas. Dua sampel yang dimaksud disini adalah sam- 
pel yang sama namun mengalamiproses pengukuran maupun perlakuan yang berbeda, sedangkan penulis menyesuaikan dengan kebutuhan penelitian sehingga tidak menggunakan uji t-paired.

Proses terbentuknya persepsi melalui beberapa tahap. Sebelum menjadi persepsi yang dapat mempengaruhi psikologis konsumen, informasi yang diterima konsumen harus mendapatkan perhatian, pemahaman, dan ingatan dari konsumen. Model pengambilan keputusan kompleks mengidentifikasi empat langkah dalam pengolahan informasi, yakni 1).Penelaahan informasi, 2). Perhatian, 3). Pemahaman, 4). Ingatan.

Pada siklus terbentuknya persepsi yang merujuk ke keputusan pembelian, penelaahan informasi terletak diluar bagian dari proses persepsi yakni antara tatanan psikologis konsumen dengan persepsi informasi yang terdiri dari perhatian, pemahaman, ingatan. Dengan demikian penelaahan informasi bukan merupakan bagian dari persepsi itu sendiri.

\section{METODE PENELITIAN}

Jenis penelitian yang dilakukan adalah deskriptif dengan metode survey. Metode survey adalah pengambilan sampel dari suatu populasi dengan menggunakan kuisioner sebagai alat untuk pengumpulan data.Selanjutnya Penelitian ini menjelaskan hubungan kausal antara variable dengan menggunakan data yang sama.

Definisi Operasional Variabel dalam penelitian ini terdiri dari variabel independen yang merupakan konsep persepsi terhadap pencantuman label halal. Variabel independen ini terdiri dari 3 variabel, yaitu: a). Variabel perhatian (X1) yang merupakan rangsangan ataupun stimulus pemasaran yang diterima oleh konsumen yang berkaitan langsung dengan produk.

Indikator dari variabel perhatian (X1) ini diantaranya adalah kuantitas rangsangan (frekuensi mendapatkan informasi), perhatian terhadap rangsangan (tingkat perhatian terhadap informasi yang diterima), tingkat kecermatan (perhatian secara detail), b). Variabel pemahaman (X2) yang merupakan proses penerjemahan dan pemahaman terhadap rangsangan yang telah diterima.

Indikatornya adalah tingkat pemahaman terhadap label halal (pengetahuan terhadap label halal), pengalaman tentang label halal produk (pengetahuan tentang produk minuman yang tidak berlabel halal), keyakinan terhadap label halal (keyakinan atas kehalalan yang dijamin oleh adanya label halal),c). Variabel ingatan (X3) yaitu hasil dari proses pemahaman yang berbentuk kesimpulan yang kemudian dapat mempengaruhi sikap dan perilaku selanjutnya. Indikatornya adalah kemampuan mengingat bentuk atau ciri-ciri label halal produk (kemampuan mengenali label halal berdasarkan bentuk), kemampuan mengingat dalam jangka panjang (ingatan terhadap label halal dalam waktu yang lama), kemudahan mengingat atribut dalam label halal (ingatan terhadap informasi yang terkandung).

Sedangkan variabel dependen dalam penelitian ini adalah keputusan pembelian konsumen (Y). Indikator dalam variabel ini adalah membeli atas dasar merek (loyalitas terhadap merek tertentu), dan membeli atas dasar jumlah (frekuensi pembelian dalam). Jenis data yang dikumpulkan adalah data primer, data dikumpulkan untuk maksud tertentu atau untuk riset tertentu. Data primer diperoleh dengan menyebarkan kuisioner yang diisi oleh responden konsumen.

Penelitian ini menggunakan data primer berupa kuisioner yang merupakan instrumen untuk mengetahui bagaimana segala sesuatu dari obyek yang diteliti. Kuisioner disebarkan untuk memperoleh data berupa jawaban-jawaban responden yang kemudian dijadikan dijadikan informasi sebagai bahan dasar pengambilan kesimpulan.

Pengujian reliabilitas digunakan untuk mengukur kestabilan dan konsistensi responden dalam menjawab hal yang berkaitan dengan daftar pertanyaan yang merupakan dimensi suatu variabel dan disusun dalam suatu bentuk koesioner. Alat ukur dikatakan memiliki reabilitas apabila instrument beberapa kali digunakan mengukur obyek yang sama. Ini berarti reliabilitas berhubungan dengan konsistensi, akurasi atau ketepatan peramalan dari hasil riset. 
Uji reliabilitas dalam penelitian ini adalah menggunakan Alpha Croanbach atau koefisien alpha. Instrumen yang digunakan dalam suatu variabel dikatakan reliable (handal) apabila memiliki koefisien alpha lebih dari 0,6.

Tabel 1 Hasil uji validitas dan Reliabilitas

\begin{tabular}{|c|c|c|c|c|c|c|}
\hline Variabel & Indikator & r hitung & $r$ tabel & Alpha Cronbach & $\mathbf{r}$ & Keterangan \\
\hline \multirow{4}{*}{ Perhatian } & $\mathrm{X} 1.1$ & 0.583 & 0.195 & \multirow{4}{*}{0.736} & \multirow{3}{*}{ Reliabel } & Valid \\
\hline & $\mathrm{X} 1.2$ & 0.716 & 0.195 & & & Valid \\
\hline & $\mathrm{X} 1.3$ & 0.644 & 0.195 & & & Valid \\
\hline & $\mathrm{X} 2.1$ & 0.646 & 0.195 & & \multirow{3}{*}{ Reliabel } & Valid \\
\hline \multirow{2}{*}{ Pemahaman } & $\mathrm{X} 2.2$ & 0.649 & 0.195 & \multirow[t]{2}{*}{0.735} & & Valid \\
\hline & $\mathrm{X} 2.3$ & 0.641 & 0.195 & & & Valid \\
\hline \multirow{3}{*}{ Ingatan } & X3.1 & 0.674 & 0.195 & \multirow{3}{*}{0.752} & \multirow{3}{*}{ Reliabel } & Valid \\
\hline & $\mathrm{X} 3.2$ & 0.719 & 0.195 & & & Valid \\
\hline & $\mathrm{X} 3.3$ & 0.579 & 0.195 & & & Valid \\
\hline \multirow{2}{*}{$\begin{array}{l}\text { Keputusan } \\
\text { Pembelian }\end{array}$} & Y1 & 0.767 & 0.195 & \multirow[b]{2}{*}{0.753} & \multirow[b]{2}{*}{ Reliabel } & Valid \\
\hline & Y2 & 0.644 & 0.195 & & & Valid \\
\hline
\end{tabular}

Dari hasil pengujian yang disajikan pada tabel 1 diatas, terlihat bahwa hubungan antara skor item dengan skor total memiliki $\mathrm{r}$ hitung $>\mathrm{r}$ tabel, sehingga dapat disimpulkan bahwa hubungan tersebut valid artinya masing-masing item pertanyaan pada kuisioner jika digunakan akan didapatkan data yang valid. Dengan hasil koefisien alpha yang melebihi koefisien reabilitas yang ditunjukan pada tabel diatas, dapat disimpulkan bahwa hubungan tersebut reliabel, artinya apabila item pertanyaan pada kuisioner digunakan beberapa kali untuk mengukur data yang sama, maka akan menghasilkan data yang sama pula.

Alat pengujian yang digunakan dalam penelitian ini adalah analisis regresi linear berganda. Analisis regresi linear berganda merupakan model statistik yang digunakan untuk mengetahui seberapa besar pengaruh variabel bebas terhadap variabel terikat dan seberapa kuat hubungan antara variabel bebas dan variabel terikat tersebut. Untuk menganalisis pengaruh variabel Pemahaman $\left(\mathrm{X}_{1}\right)$, Perhatian $\left(X_{2}\right)$, Pemahaman $\left(X_{3}\right)$ terhadap pembelian produk minuman berenergi $(\mathrm{Y})$ digunakan metode statistik dengan tingkat taraf signifikansi $\mathrm{a}=0,05$ artinya derajad kesalahan sebesar 5\%.

Hasil analisa data regresi linear berganda menunjukan nilai $\mathrm{F}_{\text {hitung }}$ sebesar 262.457 dengan signifikansi 0.000 . Nilai $F_{\text {tabel }}$ dengan pembilang sama dengan 3, dan penyebut sama dengan 96 dan á sama dengan 0.05 menunjukan angka $\mathrm{F}_{\text {tabel }}$ sama dengan 2,71. Nilai tersebut kemudian dijadikan dasar dalam melakukan uji $\mathrm{F}$, sehingga dapat diketahui bahwa $\mathrm{F}_{\text {hitung }}>\mathrm{F}_{\text {tabel }}(262.457>2,71)$, atau $\mathrm{H}_{0}$ ditolak dan $\mathrm{H}_{\mathrm{a}}$ diterima, yang artinya variable-variabel independen mempunyai pengaruh simultan yang signifikan terhadap varibel dependen.

Tabel 2 Hasil Uji t

\begin{tabular}{lcc}
\hline \multicolumn{1}{c}{ Variabel } & T & Sign \\
\hline Perhatian $(\mathrm{X} 1)$ & 2.057 & 0.042 \\
Pemahaman (X2) & -0.642 & 0.522 \\
Ingatan (X3) & 2.676 & 0.009 \\
\hline
\end{tabular}

Berdasarkan hasil perhitungan yang terlihat pada tabel 2 dapat diketahui niali $\mathrm{t}_{\text {hitung }}$ untuk variabel perhatian (X1) adalah 2.057dan $t_{\text {tabel }}$ sebesar 1.99 maka $\mathrm{t}_{\text {hitung }}$ lebih besar dari $\mathrm{t}_{\text {tabel }}$ $(2,057>1,99)$ artinya variabel perhatian (X1) mempunyai pengaruh parsial yang signifikan terhadap keputusan pembelian. Selanjutnya variabel pemahaman (X2) berdasarkan hasil perhitungan yang ditampilkan pada tabel 2 dapat diketahui nilai $\mathrm{t}_{\text {hitung }}$ untuk variabel pemahaman adalah -0.642 . Sedangkan nilai $t_{\text {tabel }} 1,99$ jika nilai $\mathrm{t}_{\text {hitung }}$ dibandingkan dengan $\mathrm{t}_{\text {tabel }}$, maka $\mathrm{t}_{\text {hitung }}$ jauh lebih kecil daripada $t_{\text {tabel }}(-0,642>1,99)$. Kemudian variabel ingatan (X3) dengan nilai $\mathrm{t}_{\text {hitung }}$ sebesar 2.676. Angka yang besar bila harus dibandingkan

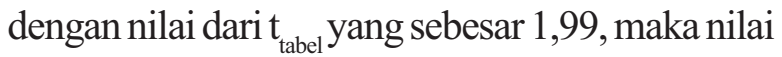


$\mathrm{t}_{\text {hitung }}$ lebih besar dari pada nilai $\mathrm{t}_{\text {tabel. }}(2,676>1,99)$. Nilai $r$ yang diperoleh dari hasil perhitungan regresi disini adalah 0.944 .

Ketentuan dalam pengukuran nilai $r$ ini adalah bila $r$ semakin mendekati negatif(-1) atau positif $(+1)$, maka semakin erat hubungan negatif atau positif antara variabel independen dengan variabel dependen. Adapun seberapa besar variasi nilai pembelian produk minuman berenergi dapat dijelasakan oleh ketiga variabel yaitu perhatian, pemahaman, dan ingatan dapat dilihat dari besaran $\mathrm{R}$ Square $\left(\mathrm{R}^{2}\right)$ pada tabel perhitungan regresi yakni sebesar $=0.891$ atau $89.1 \%$.

\section{SIMPULAN}

Dari hasil analisis setelah menghilangkan variabel pemahaman (X2) tersebut dapat diperoleh arti, variabel perhatian (X1) tetap berpengaruh parsial,yang berarti perhatian konsumen akan menurun jika konsumen tidak melakukan pemahaman tentang arti label halal yang tertera pada kemasan minuman berenergi. Dan variabel ingatan (X3) juga tetap berpengaruh parsial yang berarti konsumen akan lebih mengingat bahwa produk minuman berenergi tersebut telah berlabel halal, jikalau konsumen tidak melakukan pemahaman tentang arti dari label halal yang tertera pada kemasan minuman berenergi.

Apabila dikaitkan dengan fakta yang ada ialah, perhatian, pemahaman, dan ingatan konsumen tentang label halal pada kemasan produk minuman berenergi sangat erat kaitannya dengan keputusan pembelian yang dilakukan konsumen. Artinya konsumen melakukan keputusan pembelian minuman berenergi tidak terlepas dari proses persepsi yakni memperhatikan, memahami dan mengingat label halal yang tertera pada kemasan minuman berenergi.

Kesimpulan yang dapat diambil dari penelitian ini adalah pertama: variabel perhatian, pemahaman, dan ingatan secara simultan berpengaruh terhadap keputusan pembelian konsumen. Sedangkan diantara ketiga variabel bebas tersebut, hanya variabel pemahaman saja yang tidak berpengaruh secara parsial terhadap variabel dependen. Kedua, hasil penelitian menunjukkan tingkat hubungan atau korelasi antara vari- abel perhatian, pemahaman, ingatan dengan variabel keputusan pembelian kuat. Ini membuktikan bahwasanya keterkaitan antara perhatian, pemahaman, ingatan sangat kuat dengan keputusan pembelian konsumen.

Adapun saran yang dapat peneliti berikan diantaranya adalah bagi legislatifnegara, yaitu perlu adanya pemberian pembelajaran tentang arti halal yang mendalam bagi konsumen, karena konsumen sering kali hanya memperhatikan lalu mengingat tanpa memahami lebih dalam tentang kebenaran atau keaslian label halal yang tertera pada kemasan produk konsumsi. Ini menjadi penting karena di pasaran telah banyak beredar produk konsumsi bukan hanya minuman cair dalam botol saja yang tidak berlabel halal. Bahkan ada produk konsumsi yang berlabel halal namun secara illegal alias palsu. Terkait hal ini, dikhawatirkan konsumen akan terjebak dalam keputusan pembelian pada produk yang tidak berlabel halal ataupun berlabel halal namun palsu. Bagi produsen dan manajer pemasaran, yaitu pada setiap kegiatan promosi yang dilakukan diharapkan untuk tidak mengesampingkan penginformasian label halal, dan lebih menitikberatkan stimulus pemasaran pada atribut label halal pada produk yang dipasarkan. Hal ini bertujuan agar konsumen tidak bersikap apatis kepada produk yang menjadi pilihan konsumsinya dikarenakan adanya produk lain yang sejenis yang tidak berlabel halal ataupun berlabel halal namun palsu.

\section{DAFTAR PUSTAKA}

2010. http://id.wikipedia.org/wiki/Minuman ener gi\#Lain-lain. Diakses pada 4 April 2011

Asrim IFT. 20110. http://www.indonesiafinance today. com/read/3790/Penjualan-MinumanEnergi-Ditargetkan-Naik-10-12. Diakses pada 20 Mei 2011

Assael, Henry. 1992. Consumer Behavior and marketing Action. Fourth Edition. KENT

Husein, Umar. 2000.Metodelogi Penelitian. Jakarta. PT. Gramedia Pustaka Utama

Kotler, P dan Gary Amstrong. 2008. Prinsipprinsip Pemasaran.edisi 12 jilid 1.

PT. Prehallindo. Jakarta. 
Mashadi. 2008. Pengaruh Motivasi, Persepsi, Sikap dan Pembelajaran Konsumen Terhadap Keputusan Pembelian Minuman Kemasan Merek "Teh Botol Sosro" Dikawasan Depok.

Majalah swa.http://swa.co.id/?s=minuman+ berenergi. Diakses Pada Tanggal 20 Mei 2011

Maya, Laila. 2009. Pengaruh Persepsi Terhadap Resiko Pembelian Personal Komputer Pada Proses Pengambilan Keputusan Membeli Konsumen. Medan

Mowen, J.C dan Minor, M. 2002. Perilaku KonsumenJilid 1 Edisi Kelima. Jakarta.Erlangga

Okezone.2010. http://news.okezone.com/read/ 2010/10/09/338/380735/extra-josskembali-raih-merek-terbaik. Diakses Pada Tanggal 20 Mei 2011

Setadi, J N. 2010. Perilaku Konsumen: Persepektif Kontemporer Pada Motif, Tujuan, Dan Keinginan Konsumen. edisi revisi. Jakarta: Kencana
Sophia.2009.http://medicastore.com/artikel/262/ minuman penambah energi. Diakses pada tanggal 10 April 2011

Suliyanto.2005. Analisis Data Dalam Aplikasi Pemasaran. Bogor: Ghalia Indonesia

Tjiptono, Fandy dan Chandra, Gregorius. 2005.Service, Quality And Satisfaction. Yogyakarta. Andi Offset

Tjiptono, Fandy. 2005. Pemasaran Jasa. Edisi Pertama. Malang. Penerbit Bayu Media Publishing

Widarjono.Agus. 2010. Analisis Statistika Multifariat Terapan. Yogyakarta. UPP STIM YKPN

Widayat.2004. Metode Penelitian Pemasaran Aplikasi Software SPSS. Malang. UMM Press

http://qurandansunnah.wordpress.com/2009/11/30/ lengkap-mengetahui-makanan-haram-danhalal. Diakses 22 Mei 2011 